\title{
Informal self-employment in Kazakhstan
}

\author{
Altay Mussurov ${ }^{1 *}$ and G Reza Arabsheibani ${ }^{2,3}$
}

\author{
* Correspondence: \\ mussurov@kimep.kz \\ ${ }^{1}$ Department of Economics, KIMEP \\ University, Almaty 050010, Kazakhstan \\ Full list of author information is \\ available at the end of the article
}

\begin{abstract}
We use data from the Kazakhstan Labour Force Survey (KLFS) for the period 2006-2011 to examine factors that determine informality amongst self-employed men and women. In addition, the paper examines the response of informality propensities to the recent global crisis. The decomposition suggests that the reduction in the predicted probabilities of being informal is mainly attributable to the unexplained component. Individual characteristics have played a relatively small role, except for changes in tenure, hours of work and education.

JEL classification: P29, 017

Keywords: Self-employment, Informality; Gender; Transition
\end{abstract}

\section{Introduction}

It is generally argued that the informal sector plays an important role in the effort to reduce poverty levels and that it has a major impact on women's economic empowerment and gender equality (Kantor 2001; Chen 2012; World Bank 2013a). In addition, it has been reported that the informal sector and informal employment affects macroeconomic stability and job satisfaction (Perry et al. 2007; Fiess et al. 2010). A plethora of empirical studies have also found significant gender differences in informality rates, observed in both developed and developing countries (International Labour Organization 2002; International Labour Organization 2012). Several explanations for the documented gender gap have been proposed, often focusing on motivational differences, such as necessity and choice (Adom and Williams 2012) and differences in labour market attachments and household-level structures (Perry et al. 2007; World Bank 2012). The recent global crisis has reawakened interest in informality in general and women's informal employment in particular; and yet there appears to be some ambiguity about the effects of recession on informality, in relation to both theory and empirical evidence (Hazans 2011). ${ }^{1}$

Kazakhstan is clearly an interesting case because of the nature of its restructuring and its recent economic performance, with real GDP growth averaging $10 \%$ during the 2001-2007 commodity boom. Necessity-driven self-employment observed during the period of structural adjustment has persisted well into the 2000s, and there was also a sharp rise in the number of own-account workers during the macro-economic downturn post 2008, suggesting that self-employment correlates positively with recessions. ${ }^{2}$ Evidence also reveals that around half of all workers in the informal sector are selfemployed, mainly own-account workers (Verme 2001; Allen et al. 2007; Rutkowski

(c) 2015 Mussurov and Arabsheibani. This is an Open Access article distributed under the terms of the Creative Commons Attribution License (http://creativecommons.org/licenses/by/4.0), which permits unrestricted use, distribution, and reproduction in any medium, provided the original work is properly credited. 
2011, p. 5), and that women are 'pushed' into self-employment, as in many regions of the developing world (Duban 2012, p. 50; International Finance Corporation 2011, p. 43). According to Allen et al. (2007, p. 15), around 40\% of women in Kazakhstan start a business out of necessity, and in general the self-employed and informal workers were the most vulnerable groups during the 2008-2009 global economic crisis (Gavrilovic et al. 2009). Finally, although many empirical studies have examined the informal sector and informal employment in transition countries (e.g. Rutkowski 2006; Lehmann and Pignatti 2007; Lehmann et al. 2012; Slonimczyk and Gimpelson 2015), relatively little is known about informality in the countries of Central Asia. It is therefore interesting to contribute to the debate on informality and its causes in Central Asia's largest economy.

The objective of this paper is to identify factors that shape the informality decision amongst self-employed men and women. Additionally this paper intends to investigate the effect of the global recession on informal self-employment. We perform these analyses by estimating the choice between formal and informal selfemployment using data from the Kazakhstan Labour Force Survey (KLFS) for 2006, 2009 and 2011. ${ }^{3}$ To decompose changes over the five-year period in the average probabilities of being informal, we use a decomposition framework suggested by Gomulka and Stern (1990). The decomposition, performed separately for men and women, provides a nuanced perspective on what matters for formality and has potentially important policy implications for linking formality with development. The paper proceeds as follows. In Section 2, we provide descriptive analysis of issues related to the persistence of informal self-employment. Section 3 introduces the methodology. Section 4 describes the data set and defines the variables used in the analysis. Section 5 presents the econometric results. Section 6 concludes and presents policy applications.

\section{Background}

\subsection{The macro-economy and self-employment}

As can be seen in Table 1, real GDP growth accelerated to 13.5\% in 2001 and averaged $10 \%$ over the years 2001-2007, but fell sharply through the period of global crisis beginning in 2008, followed by the devaluation of the Kazakh tenge. ${ }^{4}$ Own-account selfemployment among those who are not engaged in subsistence farming has moderately expanded since 2001, but the gender gap had widened. ${ }^{5}$ Table 1 also reveals that the share of those who are in registered self-employment decreased during the crisis and the negative trend for females continued when growth resumed in 2010, but then rose sharply in the following year. The difference between female and male unemployment rates remains positive. Interestingly, unemployment rates fell in the late 2000s despite the recession, and men, according to the Asian Development Bank, were more successful in finding new jobs after being made redundant (Asian Development Bank 2013, p. 24).

\subsection{Informality}

Numerous common criteria define informal employment and, at the practical level, the results vary by definition (Henley et al. 2009; Kanbur 2011). However, for our purpose, informality is measured as a lack of compliance (registration) among the non- 
Table 1 Macro-economy and the labour market, 2001-2011

\begin{tabular}{|c|c|c|c|c|c|c|}
\hline \multirow[t]{3}{*}{ 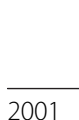 } & \multirow[t]{2}{*}{ GDP (\%) } & \multirow[t]{2}{*}{ GDP (per capita) } & \multicolumn{2}{|c|}{ Self-employment (\%) } & \multicolumn{2}{|c|}{ Unemployment (\%) } \\
\hline & & & Men & Women & Men & Women \\
\hline & 13.5 & 6146 & 15.7 & 14.3 & 8.9 & 12.0 \\
\hline 2002 & 9.8 & 6748 & 14.6 & 13.1 & 7.5 & 11.2 \\
\hline 2003 & 9.3 & 7351 & 16.5 & 15.0 & 7.2 & 10.4 \\
\hline 2004 & 9.6 & 8001 & $17.8(56.3)$ & $16.3(53.9)$ & 7.0 & 9.8 \\
\hline 2005 & 9.7 & 8699 & $17.7(59.5)$ & $15.7(58.6)$ & 6.7 & 9.6 \\
\hline 2006 & 10.7 & 9529 & $18.2(57.2)$ & $16.0(56.7)$ & 6.4 & 9.2 \\
\hline 2007 & 8.9 & 10259 & $18.6(59.2)$ & $16.3(56.6)$ & 5.9 & 8.7 \\
\hline 2008 & 3.3 & 10469 & $18.4(55.7)$ & $15.8(53.9)$ & 5.3 & 7.9 \\
\hline 2009 & 1.2 & 10318 & $19.1(56.0)$ & $16.3(54.3)$ & 5.6 & 7.5 \\
\hline 2010 & 7.3 & 10916 & $19.1(54.1)$ & $16.4(50.8)$ & 4.9 & 6.6 \\
\hline 2011 & 7.5 & 11568 & $20.0(56.2)$ & $16.8(54.3)$ & 4.6 & 6.2 \\
\hline
\end{tabular}

Notes: GDP (col. 2) = annual growth rate of GDP at market prices based on a constant tenge. GDP per capita (col. 3) $=$ GDP per capita in constant 2005 US\$ (based on PPP). Source: World Bank (2013b). Self-employment (cols. 4-5) = self-employed workers, as \% of the total employed. Self-employment status is self-assessed and consists of the following groups: employers, own-account workers, unpaid family members and members of producers' cooperatives. We exclude subsistence farmers from the estimates in cols. 4 and 5. Figures in parentheses indicate registration rates. Source: Authors' calculations from the 2001-2011 KLFS (sampling weights were used). Unemployment (cols. 6-7)= unemployment rate, as \% of the total labour force. Source: World Bank (2013b).

agricultural own-account workers. These self-employed individuals may work alone or hire occasional employees outside the purview of the state regulation.

In Table 2, we present the percentage of male and female own-account workers operating informally. The disaggregated data exhibits little variation between male and female informality rates, except for 2011. Between 2006 and 2011 informality fell 6 (8) percentage points among the self-employed men (women). However, the data reveals variations in the characteristics of men and women with respect to education. In the pre-crisis period, roughly $66 \%$

Table 2 Informality distribution by gender and education level, 2006-2011 (\%)

\begin{tabular}{|c|c|c|c|c|c|c|}
\hline \multicolumn{7}{|l|}{ Panel A. Total informality rate } \\
\hline & \multicolumn{2}{|l|}{2006} & \multicolumn{2}{|l|}{2009} & \multicolumn{2}{|l|}{2011} \\
\hline Men & \multicolumn{2}{|l|}{0.525} & \multicolumn{2}{|l|}{0.446} & \multicolumn{2}{|l|}{0.463} \\
\hline Women & \multicolumn{2}{|l|}{0.507} & \multicolumn{2}{|l|}{0.461} & \multicolumn{2}{|l|}{0.427} \\
\hline \multicolumn{7}{|c|}{ Panel B. Distribution by education level } \\
\hline & \multicolumn{6}{|l|}{ Men } \\
\hline & \multicolumn{3}{|c|}{ Formal } & \multicolumn{3}{|c|}{ Informal } \\
\hline & 2006 & 2009 & 2011 & 2006 & 2009 & 2011 \\
\hline$\leq$ Secondary/Nocational & 0.46 & 0.45 & 0.41 & 0.66 & 0.61 & 0.58 \\
\hline Technical/Incomplete Higher & 0.34 & 0.34 & 0.38 & 0.26 & 0.26 & 0.31 \\
\hline \multirow[t]{4}{*}{ Higher } & 0.20 & 0.21 & 0.21 & 0.08 & 0.12 & 0.11 \\
\hline & \multicolumn{6}{|c|}{ Women } \\
\hline & \multicolumn{3}{|c|}{ Formal } & \multicolumn{3}{|c|}{ Informal } \\
\hline & 2006 & 2009 & 2011 & 2006 & 2009 & 2011 \\
\hline$\leq$ Secondary & 0.47 & 0.38 & 0.38 & 0.61 & 0.49 & 0.47 \\
\hline Technical/Incomplete Higher & 0.36 & 0.38 & 0.39 & 0.28 & 0.33 & 0.37 \\
\hline Higher & 0.17 & 0.24 & 0.22 & 0.11 & 0.18 & 0.17 \\
\hline
\end{tabular}

Source: Authors' estimates based on KLFS data (4th quarter). Note: Weighted by KLFS sampling weights. 
(61\%) of men (women) in informal self-employment achieved a basic level of school qualifications as opposed to $46 \%$ (47\%) of men (women) in formal self-employment. That is, the majority of informal workers are those who lack the skills and education, i.e., human capital, required to make them more productive. ${ }^{6}$

We also find differing dynamics in the distribution of informality at technical and degree level of qualifications between 2006 and 2011. The percentage of women with technical education in informal self-employment rose (28\% to $37 \%)$, whilst it was relatively stable in the formal sector. Overall, Table 2 reports a negative trend in informality rates during the recent financial crisis, after which they remained below the pre-crisis levels.

In explaining the patterns of informal self-employment, we also focus on the ethnic dimension (for classification of ethnicity, see Table 3). As Table 4 demonstrates, the largest percentage decrease in rates of informality across ethnic groups was for Europeans. Whilst informality rates fell for Kazakh and European women, it rose from 48\% in 2006 to $53 \%$ in 2009 among minority women (mainly Uzbeks and Uighurs). Informality declined among Kazakh men (57\% to $49 \%$ ) but rose among minority ethnic men (46\% to $49 \%$ ) over the five-year period. Overall, the ethnic dimension of self-employment indicates the dominance of formal self-employment among Europeans. Moreover, it demonstrates that minority women have markedly higher informality rates in times of recession.

\subsection{Government policy}

In December 2012, the government announced its intention to double the SME sector's contribution to GDP by 2030 , from $17.3 \%$ to around $35 \%$. This objective is embedded

Table 3 Definitions of variables

\begin{tabular}{|c|c|}
\hline & Specification \\
\hline \multicolumn{2}{|c|}{ Panel A. Dependent } \\
\hline Self-employed & 0 = paid employment; 1 = own-account (independent) self-employment. \\
\hline \multirow[t]{2}{*}{ Informal } & $\begin{array}{l}1=\text { unregistered entrepreneurship/unlicensed economic activity, formalising the } \\
\text { registration, or the respondent does not know. }\end{array}$ \\
\hline & $0=$ registered entrepreneurship or licensed economic activity (formal). \\
\hline \multicolumn{2}{|c|}{ Panel B. Explanatory } \\
\hline Age & Age (years). \\
\hline Children & Number of children in the household below the age of 5 . \\
\hline Education & $\begin{array}{l}4=\text { less than secondary, } 8=\text { incomplete secondary, } 10=\text { complete secondary or } \\
\text { vocational, } 12=\text { technical or incomplete higher, } 15=\text { higher or postgraduate. }\end{array}$ \\
\hline Married & 1 = Married. \\
\hline Kazakh & $1=$ Kazakh. \\
\hline European & 1 = Belarusian, German, Greek, Russian or Ukrainian. \\
\hline Tenure & $\begin{array}{l}\text { Years in current business } / \text { Tenure in current employment. } 1=\text { less than } 6 \text { months, } \\
2=6-12 \text { months, } 3=1-3 \text { years, } 4=3-5 \text { years, } 5=\text { more than } 5 \text { years. }\end{array}$ \\
\hline Hours & Usual work hours (per week) in the main job. \\
\hline Professional & $\begin{array}{l}1=\text { Architects, Chemists, Computer Specialists, Dentists, Doctors, Engineers, Lawyers, } \\
\text { Managers, Mathematicians, Physicists, Public Officials, Pharmacists, School Teachers, } \\
\text { Scientists, Statisticians, College or University Lecturers. }\end{array}$ \\
\hline Urban & 1 = Urban location except Almaty and Astana. \\
\hline Almaty/Astana & 1 = Almaty or Astana. \\
\hline \multicolumn{2}{|c|}{ Panel C. Identifying } \\
\hline Experience & $1=$ previous experience of attempting to start own business. \\
\hline
\end{tabular}


Table 4 Informality rates by gender and ethnicity, 2006-2011 (\%)

\begin{tabular}{|c|c|c|c|c|}
\hline & \multicolumn{3}{|l|}{ Men } & \multirow[b]{2}{*}{$\Delta$ 2006-2011 (\%) } \\
\hline & 2006 & 2009 & 2011 & \\
\hline Kazakh & 57.4 & 48.1 & 49.4 & -14 \\
\hline European & 45.5 & 36.3 & 35.8 & -21 \\
\hline \multirow[t]{3}{*}{ Minority } & 46.4 & 46.1 & 49.4 & 6 \\
\hline & \multicolumn{3}{|c|}{ Women } & \multirow[b]{2}{*}{$\Delta$ 2006-2011 (\%) } \\
\hline & 2006 & 2009 & 2011 & \\
\hline Kazakh & 53.6 & 49.5 & 47.0 & -12 \\
\hline European & 46.4 & 38.2 & 33.3 & -28 \\
\hline Minority & 48.4 & 52.6 & 41.7 & -14 \\
\hline
\end{tabular}

Source: Authors' estimates based on KLFS data (4th quarter).

Note: Weighted by KLFS sampling weights.

in the 'Kazakhstan-2050' long-term development strategy. However, we propose that for the initiative to be effective, the government must implement policies that will reduce informality levels. A number of factors, of course, can explain why the selfemployed in Kazakhstan choose to operate informally. Rutkowski (2011, p. 17) has argued that the cost of social protection associated with formal self-employment exceeds the benefits, thereby acting as a barrier to register as self-employed. Informal self-employment offers the flexibility of working hours for women, allowing a better balance of work and family life, and provides opportunities for the lessskilled individuals to generate income, mainly in trade-related activities (Asian Development Bank 2013, p. 42). At the same time, women engaged in these activities encounter borrowing constraints, preventing their entry into the formal sector (Asian Development Bank 2013, pp. 42-43).

Own-account workers have access to SME assistance programmes, delivered by the Damu Entrepreneurship Development Fund through the various forms of interventions and capacity building initiatives, including training and information-based assistance, the loan guarantee schemes, leasing finance and interest subsidies. Table 5 shows that targeted loans totalled US\$3.93bn between 2009 and 2011. However, men were the primary loan

Table 5 Government-funded lending programmes, 2009-2011

\begin{tabular}{|c|c|c|c|c|}
\hline & \multicolumn{2}{|c|}{ Aggregate recipients } & \multicolumn{2}{|c|}{ Women recipients } \\
\hline & Clients & Volume (US\$) & Clients & Volume (US\$) \\
\hline Stabilisation Programme & 9057 & $\$ 3.21 \mathrm{bn}$ & 2382 & $\$ 252.06 \mathrm{~m}$ \\
\hline Regions & 1555 & $\$ 391.62$ m & 368 & $\$ 29.42 \mathrm{~m}$ \\
\hline Manufacturing & 222 & $\$ 296.79 \mathrm{~m}$ & 22 & $\$ 3.60 \mathrm{~m}$ \\
\hline Women Entrepreneurship & 547 & $\$ 16.19 \mathrm{~m}$ & 547 & $\$ 16.19 \mathrm{~m}$ \\
\hline Leasing Finance & 49 & $\$ 8.68 \mathrm{~m}$ & 0 & 0 \\
\hline Zhanaozen & 22 & $\$ 1.31 \mathrm{~m}$ & 6 & $\$ 150788$ \\
\hline Regional Funding & 17 & $\$ 7.31 \mathrm{~m}$ & 0 & 0 \\
\hline Total & 11469 & $\$ 3.93 \mathrm{bn}$ & 3325 & $\$ 301.42 \mathrm{~m}$ \\
\hline
\end{tabular}

Source: Damu Fund, 2011 Chairperson's Report.

Notes: We converted the volumes of loans, denominated in domestic currency (as of 1 August 2011), using the official exchange rate for July 2011 ( $\$ 1=145.90$ tenge). Estimates for the female recipients are shown in the last two columns, as reported in the data source. The Zhanaozen programme was initiated following the outbreak of industrial conflict in the town. 
recipients, and self-employed women were excluded from leasing finance and access to the regional funding systems. In any of the financial support programmes with women borrowers, the percentage of women loan recipients does not exceed 30\%, except for the women-only lending programme. It needs to be emphasised that these loans covered only 547 women who borrowed, on average, around US\$ 30,000. Given the importance of microfinance for informal workers in terms of entrepreneurial entry and survival (Demirgüc-Kunt et al. 2010), it appears that governmental concerns need to focus on building up microfinance institutions and gender-specific lending initiatives. ${ }^{7}$

The analysis of informality patterns in the aggregate data has shown that informal workers are more likely to report lower levels of education and skills and to belong to the ethnic minority groups. The data show, for both men and women, that the trend of informal self-employment substantially declined between 2006 and 2011; but according to Asian Development Bank (2013), women continue to have fewer job opportunities outside of the informal sector than men. In the following sections, we explore these insights into the nature of informal self-employment further.

\section{Methodology}

In the second half of the 20th century, economists developed a number of theoretical models that may serve in analysing worker participation in informal employment. These models can be distinguished by the underlying causes to which they attribute reasons for selecting employment in this sector. The traditional view argues that workers enter the informal sector because they do not have alternative sources of income (e.g., Fields 1975). This is because "unemployment in the city is a distinct possibility" for workers excluded from formal sector employment (Fields 1990, p. 50). This view effectively considers the informal sector a stepping stone (the "staging area hypothesis"), which rural migrants enter to earn income to finance their job search in the formal sector. Another strand challenges the segmentation view, arguing that majority of workers in the informal sector have voluntarily chosen that sector and that the traditional dualistic view can become "more relevant in the presence of deep recession and large labor distortions" (Maloney 2004, p. 1173).

In seeking to explain the process of sector choice, it is natural to follow Hart's (1972, 1973) proposition that the informal (undocumented) sector is not intrinsically bad. Relying on the rational choice argument, we can assume that workers may freely choose informal activity and that the decision to become an informal worker depends on the risk-adjusted relative rewards. Indeed, informality in self-employment offers benefits - such as tax evasion - as well as the measurable uncertainty associated with the risk of detection. Therefore, a decision on whether or not to engage in informal self-employment activities can be seen as the outcome of random utility maximization based on the individual's perception of whether the utility stream from unregistered self-employment exceeds that of a legally registered activity. ${ }^{8}$ For example, Staneva and Arabsheibani (2013) have shown that in Tajikistan the average post-tax earnings in the informal sector are higher than in the formal sector. Additionally, Gimpelson and Kapeliushnikov (2013) have shown that informality carries an earnings premium among Russia's self-employed workers. This situation obviously creates incentives to choose informal self-employment. Overall, we can treat the utility function as a black box, but in principle it reflects expected benefits (e.g., pension contribution evasion) as well as expected costs (e.g., maintaining a book of accounts). We also assume that switching between the two (legal and illegal) states is costly and that individuals 
demonstrate heterogeneous aversion to risk. For example, more risk-averse (e.g., more educated) individuals are more likely to operate registered businesses.

For empirical specification, we approximate the utility function with the following 'latent' Eqn. (1):

$$
I_{i}^{*}=X_{i} \gamma+\varepsilon_{i}
$$

where $I_{i}^{*}$ is the (unobservable) discrete choice variable indicating the decision of whether to register or not for individual $i . X_{i}$ is a set of explanatory variables, $\gamma$ is the corresponding vector of coefficients and $\varepsilon_{i} \sim N(0,1)$ is the error term.

Since $I_{i}^{*}$ is latent, the observed realisation of the index function is indicated by the following binary outcome:

$$
\begin{aligned}
& I_{i}=1 \text { if } I_{i}^{*}>0(\text { informal }) \\
& I_{i}=0 \text { if } I_{i}^{*}=0(\text { formal })
\end{aligned}
$$

However, if selection into self-employment is not random, then the relationship between the self-employment decision (selection equation) and informality (outcome) can be formed through observable and unobservable characteristics. And if these characteristics are correlated, this will generate an incorrect conclusion regarding the impact of the observable characteristics on the choice of informality. ${ }^{9}$ Thus, we apply the equivalent of Heckman's selection model (the bivariate probit model with sample selection) to correct for the possibility of sample selection bias. ${ }^{10}$

The selection equation is determined by the following function:

$$
S_{i}=Z_{i} \beta+u_{i}
$$

where $S_{i}$ is the binary choice variable indicating the endogenous selection process that determines the decision to enter self-employment. $Z_{i}$ is a vector of the observed characteristics, $\beta$ is the corresponding vector of coefficients and $u_{i} \sim N(0,1)$ is the error term.

The decision to enter self-employment is indicated by:

$$
\begin{aligned}
& \mathrm{S}=1 \text { if } Z_{i} \beta+u_{i}>0 \text { (self-employed) } \\
& \mathrm{S}=0 \text { if } Z_{i} \beta+u_{i} \leq 0 \text { (paid employment) }
\end{aligned}
$$

From Eqs. (1) and (4), it is clear that $X$ and $Z$ have a bivariate normal distribution with zero means and correlation $\rho(\rho \neq 0)$ and that three types of observations exist, with the following probabilities:

$$
\begin{aligned}
& \mathrm{S}=0 \operatorname{Pr}\left(S_{i}=0\right)=\Phi\left(-Z_{i} \beta\right) \\
& \mathrm{S}=1, \mathrm{I}=0 \operatorname{Pr}\left(S_{i}=1, I_{i}=0\right)=\Phi\left(Z_{i} \beta\right)-\Phi_{2}\left(Z_{i} \beta, X_{i} \gamma, \rho\right) \\
& \mathrm{S}=1, \mathrm{I}=1 \operatorname{Pr}\left(S_{i}=1, I_{i}=1\right)=\Phi_{2}\left(Z_{i} \beta, X_{i} \gamma, \rho\right),
\end{aligned}
$$

where $\Phi(\cdot)$ is the standard normal distribution function, and $\Phi_{2}(\cdot)$ is the bivariate normal distribution function.

The double probit model can be estimated by fitting maximum-likelihood probit models with sample selection. The correlation between the two residuals in the selection and outcome (informality) equations in the maximum likelihood estimation 
is not directly estimated. Instead, the inverse of the hyperbolic tangent is estimated as follows:

$$
\operatorname{atanh} \rho=\frac{1}{2} \ln \left(\frac{1+\rho}{1-\rho}\right)
$$

Conditions of the double probit model require at least one variable to be included in $Z_{i}$ that does not also appear in $X_{i}$. Identification restrictions are required to achieve efficiency, and therefore we need a variable that we think affects selection into the sector, but not the informality choice. However, few candidates usually exist for the inclusion of additional variables in $Z_{i}$.

To decompose the predicted changes in informality, we use the non-linear decomposition technique proposed by Gomulka and Stern (1990) and Even and Macpherson (1993) for binary outcomes in which counterfactual conditional expectations are computed and averaged across observations. The decomposition is expressed in terms of probabilities. Specifically, the univariate (marginal) predicted probability of success $(I=1)$ is estimated as the sum of probabilities:

$$
\operatorname{Pr}\left(I_{i}=1\right)=\Phi\left(X_{i} \gamma\right)
$$

Using the second-stage probit coefficients, the average predicted probability of informality for an individual in group $j(j=m, f)$, male or female, and time $t(t=0,1)$ is expressed as:

$$
P\left(X_{j t}, \hat{\gamma}_{j t}\right)=\left(1 / n_{j t}\right) \sum_{i=1}^{n_{j t}} \Phi\left(X_{i j t} \hat{\gamma}_{j t}\right)
$$

and the predicted change in informality between two periods ( 0 and 1$)$ is then expressed as:

$$
\Delta I G A P=\bar{I}_{j 1}-\bar{I}_{j 0}=P\left(X_{j 1}, \hat{\gamma}_{j 1}\right)-P\left(X_{j 0}, \hat{\gamma}_{j 0}\right)
$$

Using the baseline structure for period 0 as the reference, we can decompose the change into explained and unexplained portions of the gap as follows:

$$
\begin{aligned}
& \operatorname{EXP}_{j \Delta_{t}}=\left[P\left(X_{j 1}, \hat{\gamma}_{j 0}\right)-P\left(X_{j 0}, \hat{\gamma}_{j 0}\right)\right] \\
& \operatorname{UNEXP}_{j \Delta_{t}}=\left[P\left(X_{j 0}, \hat{\gamma}_{j 1}\right)-P\left(X_{j 0}, \hat{\gamma}_{j 0}\right)\right],
\end{aligned}
$$

where the change in endowments explains the difference in informality rates between the two periods in the explained component, attributed to the change in observable characteristics over time for a single group, whilst the unexplained component is caused by the change in the underlying structures determining informality between the two periods. ${ }^{11}$

Given that the explained component is a sum over the individual contributions, the contribution to the explained component (Eqn. 14) made by the $r^{\text {th }}$ regressor is equal to:

$$
E X P_{j r \Delta_{t}}=\left[P\left(X_{j 1}, \hat{\gamma}_{j 0}\right)-P\left(X_{j 0}, \hat{\gamma}_{j 0}\right)\right]\left[\frac{\left(\bar{X}_{j r 1}-\bar{X}_{j r 0}\right) \hat{\gamma}_{j r 0}}{\left(\bar{X}_{j 1}-\bar{X}_{j 0}\right) \hat{\gamma}_{j 0}}\right],
$$

where the weighted contributions of the $r^{\text {th }}$ individual predictor is determined by the group difference in means and evaluated by using coefficient estimates from the double probit model. ${ }^{12}$ 


\section{Data}

The KLFS is a longitudinal (rotating) household-based survey conducted quarterly with a sample size of 21,000 households, $75 \%$ of which is held over for the next wave, with the rest dropped and replaced by new households. In 2011, however, every household in the sample was replaced by a new set of households. The present study draws its sample from the fourth quarter of the 2006, 2009 and 2011 KLFS.

The survey collects data on a national sample of households randomly selected from a register of dwellings based on the territorial division of the housing register to ensure that each household has an equal probability of being selected. The compilation of the housing register was part of the 1999 and 2009 National Population Surveys. The first wave was conducted in 2001 by the Kazakhstan Agency on Statistics, but information on labour market tenure was first collected in the 2006 wave of the survey.

The labour market questionnaire, answered by all individuals in the household over the age of 15, provides information on the labour related characteristics (e.g., informal employment, social security coverage and trade union affiliations) and work related characteristics (e.g., industry, occupation and status in employment). In accordance with the ILO, the respondent is considered employed if he/she worked for at least one hour in the past seven days and received some form of monetary payment or payment in kind. Interviews were conducted in all 14 regions of the country, including the capital city, Astana, and the financial capital, Almaty.

The data contains no information on a person's wage rate or income, a major weakness inherent in the survey. ${ }^{13}$ Occupations are grouped by the degree of similarity in their constituent tasks and duties. We use the classification of occupations, reproduced from the International Standard Classification of Occupations (International Labour Organization 1990), to create a control variable for occupations that require a high level of job-related skills (Professional), as informal sector earnings are not uniformly lower.

To focus on working age adults, we have restricted our sample to individuals aged 16 and above by excluding students, children under 16 years of age, pensioners and the unemployed. We also exclude other groups of self-employed workers: unpaid family members, subsistence farmers and members of worker co-operatives and others who work in the agricultural sector. This is done in accordance with most other studies on the subject because most agriculturalists, in particular subsistence farmers, are household-firms rather than either households or firms. ${ }^{14}$ The definition of informality relies on the enterprise-based criterion that considers own-account enterprises informal if they failed to register. In the selection equation, paid workers and employers form the reference category (salaried workers). In Table 4, we describe the main variables derived from the survey. Descriptive statistics are given in Table 6.

Estimates that rely on a functional form for identification are usually unstable, and stronger identification restrictions are required to achieve efficiency. Therefore, we use previous self-employment experience as an exclusion restriction to identify the model. We argue that this variable affects the self-employment choice but is not related to the probability of informality.

\section{Empirical results}

5.1 Selection estimates

In the first step of our analysis, we measure the probability of sector choice (selfemployment or salaried work) against the selected independent variables. The base 
Table 6 Summary statistics

\begin{tabular}{|c|c|c|c|c|c|c|c|c|c|c|c|c|}
\hline & \multicolumn{6}{|l|}{ Men } & \multicolumn{6}{|l|}{ Women } \\
\hline & \multicolumn{3}{|l|}{ Formal } & \multicolumn{3}{|l|}{ Informal } & \multicolumn{3}{|l|}{ Formal } & \multicolumn{3}{|l|}{ Informal } \\
\hline & 2006 & 2009 & 2011 & 2006 & 2009 & 2011 & 2006 & 2009 & 2011 & 2006 & 2009 & 2011 \\
\hline Age & $40.12(11.16)$ & $39.21(11.05)$ & 39.41 (11.48) & $36.44(10.94)$ & $39.17(11.43)$ & 37.57 (11.57) & $39.30(10.48)$ & $40.11(10.39)$ & $38.84(11.14)$ & $37.30(11.03)$ & $39.14(10.84)$ & 37.49 (11.56) \\
\hline Children & $0.184(0.388)$ & $0.226(0.418)$ & $0.226(0.419)$ & $0.183(0.387)$ & $0.240(0.427)$ & $0.271(0.445)$ & $0.143(0.351)$ & $0.202(0.401)$ & $0.227(0.419)$ & $0.158(0.365)$ & $0.230(0.421)$ & $0.268(0.443)$ \\
\hline Education & $11.58(1.926)$ & $11.60(1.977)$ & 11.69 (1.955) & $10.87(1.655)$ & $10.97(1.802)$ & $11.06(1.683)$ & $11.54(1.87)$ & $11.82(1.99)$ & 11.85 (1.91) & $11.10(1.78)$ & $11.46(1.91)$ & $11.46(1.84)$ \\
\hline Married & $0.760(0.428)$ & $0.718(0.450)$ & $0.701(0.458)$ & $0.638(0.481)$ & $0.693(0.462)$ & $0.662(0.473)$ & $0.657(0.475)$ & $0.622(0.485)$ & $0.617(0.486)$ & $0.616(0.487)$ & $0.675(0.469)$ & $0.594(0.491)$ \\
\hline Kazakh & $0.510(0.500)$ & $0.554(0.497)$ & $0.579(0.494)$ & $0.618(0.486)$ & $0.650(0.477)$ & $0.650(0.477)$ & $0.527(0.500)$ & $0.533(0.500)$ & $0.577(0.494)$ & $0.591(0.492)$ & $0.616(0.486)$ & $0.661(0.474)$ \\
\hline European & $0.332(0.471)$ & $0.323(0.468)$ & $0.273(0.446)$ & $0.256(0.437)$ & $0.229(0.421)$ & $0.170(0.376)$ & $0.368(0.482)$ & $0.386(0.487)$ & $0.299(0.458)$ & $0.313(0.464)$ & $0.272(0.445)$ & $0.207(0.405)$ \\
\hline Tenure & $3.63(1.21)$ & $3.67(1.20)$ & 3.74 (1.28) & $3.05(1.34)$ & 3.35 (1.36) & $3.62(1.32)$ & $3.54(1.22)$ & $3.69(1.23)$ & $3.60(1.32)$ & $2.92(1.37)$ & $3.06(1.34)$ & $3.34(1.35)$ \\
\hline Hours & $40.81(7.44)$ & $40.86(6.75)$ & $40.84(6.69)$ & $37.12(10.59)$ & $40.10(8.03)$ & $39.87(7.961)$ & $40.06(7.74)$ & $39.70(7.37)$ & $39.89(6.61)$ & $35.71(11.61)$ & $38.88(7.51)$ & 38.37 (8.134) \\
\hline Professional & $0.034(0.182)$ & $0.043(0.203)$ & $0.047(0.211)$ & $0.014(0.119)$ & $0.017(0.130)$ & $0.011(0.106)$ & $0.030(0.171)$ & $0.045(0.207)$ & $0.054(0.227)$ & $0.034(0.181)$ & $0.024(0.152)$ & $0.029(0.168)$ \\
\hline Urban & $0.515(0.500)$ & $0.472(0.499)$ & $0.476(0.500)$ & $0.571(0.495)$ & $0.472(0.500)$ & $0.524(0.500)$ & $0.536(0.499)$ & $0.547(0.498)$ & $0.509(0.500)$ & $0.684(0.465)$ & 0.535 (0.499) & $0.569(0.496)$ \\
\hline Almaty/Astana & $0.092(0.289)$ & $0.070(0.255)$ & $0.091(0.287)$ & $0.028(0.164)$ & $0.054(0.226)$ & $0.039(0.194)$ & $0.091(0.287)$ & $0.047(0.212)$ & $0.069(0.254)$ & $0.023(0.151)$ & $0.043(0.202)$ & $0.031(0.172)$ \\
\hline Experience & $0.451(0.498)$ & $0.425(0.495)$ & $0.3905(0.391)$ & $0.257(0.437)$ & $0.131(0.337)$ & $0.131(0.337)$ & $0.444(0.497)$ & $0.431(0.495)$ & $0.460(0.498)$ & $0.234(0.424)$ & $0.100(0.300)$ & $0.098(0.298)$ \\
\hline $\mathrm{N}$ & 815 & 1120 & 1247 & 832 & 872 & 1053 & 795 & 1022 & 995 & 771 & 800 & 721 \\
\hline
\end{tabular}

Notes: Standard deviations are in parentheses. Data are unweighted. 
outcome, we argue, offers greater job security than self-employment work because of the regulating provisions and additional benefits.

Table 7 reports the estimates. For women, the estimated age effect suggests that older workers are more likely to be self-employed during the crisis (see column 6 of Table 7). The impact of having dependent children became positive and significant in 2009 and 2011, possibly suggesting that there has been an increase in the costs of childcare. ${ }^{15}$ We find that education is negatively associated with self-employment propensity in every year for both women and men. Several explanations may account for this phenomenon. Education may be correlated with tastes for leisure and subsequently may favour under-employment (e.g., government work). It could also lower the search costs for paid work relative to self-employment by satisfying job requirements. Another possible reason for the negative effect of education on self-employment is that education may correlate positively

Table 7 Selection equation estimation results

\begin{tabular}{|c|c|c|c|c|c|c|}
\hline \multirow[b]{2}{*}{ Variable } & \multicolumn{3}{|l|}{ Men } & \multicolumn{3}{|l|}{ Women } \\
\hline & 2006 & 2009 & 2011 & 2006 & 2009 & 2011 \\
\hline \multirow[t]{2}{*}{ Age } & $-0.003^{c}$ & 0.001 & -0.0004 & $-0.004^{b}$ & $0.006^{\mathrm{a}}$ & -0.002 \\
\hline & $(0.002)$ & $(0.002)$ & $(0.001)$ & $(0.002)$ & $(0.002)$ & $(0.002)$ \\
\hline \multirow[t]{2}{*}{ Children } & -0.023 & 0.031 & 0.051 & -0.033 & $0.109^{b}$ & $0.129^{b}$ \\
\hline & $(0.046)$ & $(0.038)$ & $(0.036)$ & $(0.051)$ & $(0.041)$ & $(0.040)$ \\
\hline \multirow[t]{2}{*}{ Education } & $-0.083^{a}$ & $-0.077^{\mathrm{a}}$ & $-0.111^{a}$ & $-0.108^{a}$ & $-0.060^{a}$ & $-0.110^{\circ}$ \\
\hline & $(0.010)$ & $(0.008)$ & $(0.008)$ & $(0.010)$ & $(0.009)$ & $(0.009)$ \\
\hline \multirow[t]{2}{*}{ Married } & -0.028 & 0.017 & $-0.075^{\mathrm{b}}$ & 0.057 & 0.024 & $-0.079^{k}$ \\
\hline & $(0.045)$ & $(0.039)$ & $(0.038)$ & $(0.038)$ & $(0.034)$ & $(0.035)$ \\
\hline \multirow[t]{2}{*}{ Kazakh } & $-0.366^{a}$ & $-0.302^{\mathrm{a}}$ & $-0.426^{a}$ & $-0.150^{b}$ & $-0.206^{\mathrm{a}}$ & $-0.385^{\mathrm{a}}$ \\
\hline & $(0.056)$ & $(0.053)$ & $(0.046)$ & $(0.063)$ & $(0.060)$ & $(0.057)$ \\
\hline \multirow[t]{2}{*}{ European } & $-0.589^{a}$ & $-0.524^{a}$ & $-0.657^{a}$ & $-0.393^{a}$ & $-0.403^{a}$ & $-0.671^{\circ}$ \\
\hline & $(0.058)$ & $(0.055)$ & $(0.051)$ & $(0.065)$ & $(0.061)$ & $(0.060)$ \\
\hline \multirow[t]{2}{*}{ Tenure } & $-0.095^{a}$ & $-0.077^{\mathrm{a}}$ & $-0.054^{a}$ & $-0.142^{\mathrm{a}}$ & $-0.150^{a}$ & $-0.118^{\mathrm{a}}$ \\
\hline & $(0.014)$ & $(0.013)$ & $(0.013)$ & $(0.014)$ & $(0.013)$ & $(0.014)$ \\
\hline \multirow[t]{2}{*}{ Hours } & $-0.027^{a}$ & $-0.009^{b}$ & $-0.013^{a}$ & $-0.024^{a}$ & $-0.018^{a}$ & $-0.016^{\mathrm{a}}$ \\
\hline & $(0.003)$ & $(0.003)$ & $(0.003)$ & $(0.003)$ & $(0.003)$ & $(0.003)$ \\
\hline \multirow[t]{2}{*}{ Professional } & $-0.711^{a}$ & $-0.560^{a}$ & $-0.611^{a}$ & $-0.878^{a}$ & $-0.979^{a}$ & $-0.825^{\circ}$ \\
\hline & $(0.091)$ & $(0.068)$ & $(0.066)$ & $(0.077)$ & $(0.066)$ & $(0.063)$ \\
\hline \multirow[t]{2}{*}{ Urban } & $-0.182^{a}$ & $-0.121^{a}$ & $-0.131^{\mathrm{a}}$ & -0.001 & -0.031 & $-0.102^{\mathrm{t}}$ \\
\hline & $(0.038)$ & $(0.033)$ & $(0.032)$ & $(0.039)$ & $(0.035)$ & $(0.035)$ \\
\hline \multirow[t]{2}{*}{ Almaty/Astana } & $-0.476^{a}$ & $-0.546^{\mathrm{a}}$ & $-0.472^{a}$ & $-0.349^{a}$ & $-0.631^{a}$ & $-0.459^{\circ}$ \\
\hline & $(0.067)$ & $(0.059)$ & $(0.055)$ & $(0.070)$ & $(0.068)$ & $(0.067)$ \\
\hline \multirow[t]{2}{*}{ Experience } & $1.544^{\mathrm{a}}$ & $1.439^{\mathrm{a}}$ & $1.491^{\mathrm{a}}$ & $1.590^{\mathrm{a}}$ & $1.597^{\mathrm{a}}$ & $1.671^{\mathrm{a}}$ \\
\hline & $(0.047)$ & $(0.046)$ & $(0.048)$ & $(0.051)$ & $(0.052)$ & $(0.052)$ \\
\hline \multirow[t]{2}{*}{ Constant } & $1.943^{\mathrm{a}}$ & $0.852^{\mathrm{a}}$ & $1.689^{\mathrm{a}}$ & $1.970^{\mathrm{a}}$ & $1.004^{\mathrm{a}}$ & $1.913^{\mathrm{a}}$ \\
\hline & $(0.172)$ & $(0.172)$ & $(0.165)$ & $(0.179)$ & $(0.178)$ & $(0.190)$ \\
\hline N (total) & 10527 & 11827 & 11608 & 10600 & 11437 & 11719 \\
\hline
\end{tabular}

Notes: Unweighted regressions. Robust standard errors are in parentheses. Coefficients in bold are significant at: ${ }^{a} p<0.001$, ${ }^{b} \mathrm{p}<0.01,{ }^{\mathrm{c}} \mathrm{p}<0.05$.

Dependent variable $=$ Self-employed. 
with risk aversion. Finally, this result could be explained by the employers setting strong criteria for applicants seeking wage employment.

Noticeable differences exist in the probability of entering self-employment for ethnic minorities. The higher propensity to be self-employed for ethnic minorities may be attributed to unobserved differences between ethnic groups (Parker 2004, pp. 123-124). In general, for both genders, the coefficients of being a professional, hours of work and tenure are significantly negative. Spatial variations in self-employment propensities suggest that, for men, these propensities are negative in urban areas and the two city locations with higher-than-average levels of income, Almaty and Astana. These findings may be explained by the housing bubble, which had over-stimulated the economy in urban locations and, in turn, led rural-urban migrants to anticipate more permanent paid employment than was actually available. It is also plausible to assume that rent is more expensive in urban locations, as asserted by Parker (2004, pp. 99-102). The estimated effect of the exclusion restriction (Experience) is positive and significant, suggesting that individuals with previous self-employment experience have a higher tendency to choose the self-employed sector.

How do these results compare to the previous empirical studies of Kazakhstan and other countries? Verme (2001), using the 1996 Kazakhstan Living Standards Measurement Survey, reports that household characteristics and differences in locality explain women's participation in self-employment. Aidis et al. (2007) analysed survey data from Ukraine collected in the summer of 2002. The authors conclude that gendered norms and values, as well as institutional deficiencies, restrict women's self-employment opportunities. Also, non-pecuniary motivation such as flexibility (Burke et al. 2002), educational choices (Leoni and Falk 2008), work values (Terrell and Troilo 2010), differences in human capital and labour market experience (Georgellis et al. 2005) often explain the determinants of women's self-employment decision.

\subsection{Informality estimates}

Table 8 displays the estimated informality equations. The determinants of self-employment largely overlap with causes of informality. Estimates show that there is a positive relationship between age and the propensity to be informal in 2009, suggesting that age effects on informality are stronger for older workers in the crisis period (see columns 3 and 9 of Table 8$).{ }^{16}$ For men, we find that the presence of children increases the probability of informality in the post-crisis period. For both men and women, informality probabilities decrease with education, which is consistent with high opportunity cost of being informal. Our finding on the effect of ethnicity is that the crisis aggravated tendencies toward being informal among minority ethnic groups. European men (women) were 6.6 (5.8) percentage points more likely to be formal during the crisis of 2009. It is, of course, possible that Europeans possess better skills not captured by the available variables.

The marginal effects associated with self-employment tenure have a negative effect on informality propensities. We find that working fewer hours increases informality probabilities. Qualified professionals are more likely to be formal than nonprofessionals, although the marginal effect falls from 12 percentage points in 2006 to 6 percentage points in 2009 for men. Self-employed women living in the two largest cities tend to register as self-employed, but the magnitude is dissimilar across time. That is, the negative marginal effect was 13.5 percentage points in 2006 and 2.1 
Table 8 Informality equation estimation results (marginal effects)

\begin{tabular}{|c|c|c|c|c|c|c|c|c|c|c|c|c|}
\hline \multirow[b]{3}{*}{ Variable } & \multicolumn{6}{|l|}{ Men } & \multicolumn{6}{|l|}{ Women } \\
\hline & \multicolumn{3}{|c|}{ Double probit } & \multicolumn{3}{|l|}{ Probit } & \multicolumn{3}{|c|}{ Double probit } & \multicolumn{3}{|l|}{ Probit } \\
\hline & 2006 & 2009 & 2011 & 2006 & 2009 & 2011 & 2006 & 2009 & 2011 & 2006 & 2009 & 2011 \\
\hline \multirow[t]{2}{*}{ Age } & $-0.003^{b}$ & $0.001^{b}$ & $-0.001^{b}$ & $-0.004^{b}$ & $0.002^{c}$ & $-0.003^{b}$ & $-4 \times 10^{-4}$ & $0.001^{b}$ & $4 \times 10^{-5}$ & $-3 \times 10^{-4}$ & 0.001 & -0.001 \\
\hline & $(0.001)$ & $(0.000)$ & $(0.001)$ & $(0.001)$ & $(0.001)$ & $(0.001)$ & $(0.001)$ & $(0.0003)$ & $(0.0002)$ & $(0.001)$ & $(0.001)$ & $(0.001)$ \\
\hline \multirow[t]{2}{*}{ Children } & 0.002 & 0.015 & $0.023^{c}$ & -0.003 & 0.015 & $0.046^{c}$ & -0.008 & 0.011 & 0.010 & -0.006 & 0.005 & 0.028 \\
\hline & $(0.027)$ & $(0.012)$ & $(0.013)$ & $(0.036)$ & $(0.029)$ & $(0.026)$ & $(0.026)$ & $(0.008)$ & $(0.008)$ & $(0.038)$ & $(0.030)$ & $(0.029)$ \\
\hline \multirow[t]{2}{*}{ Education } & $-0.032^{a}$ & $-0.020^{\mathrm{a}}$ & $-0.027^{\mathrm{a}}$ & $-0.038^{\mathrm{a}}$ & $-0.040^{\mathrm{a}}$ & $-0.038^{\mathrm{a}}$ & $-0.024^{a}$ & $-0.007^{a}$ & $-0.011^{a}$ & $-0.027^{\mathrm{a}}$ & $-0.017^{b}$ & $-0.022^{b}$ \\
\hline & $(0.006)$ & $(0.003)$ & $(0.003)$ & $(0.008)$ & $(0.006)$ & $(0.006)$ & $(0.006)$ & $(0.002)$ & $(0.002)$ & $(0.008)$ & $(0.006)$ & $(0.007)$ \\
\hline \multirow[t]{2}{*}{ Married } & -0.006 & -0.013 & -0.006 & -0.012 & -0.022 & -0.011 & -0.006 & $0.014^{b}$ & -0.007 & -0.010 & $0.057^{b}$ & -0.023 \\
\hline & $(0.026)$ & $(0.012)$ & $(0.013)$ & $(0.035)$ & $(0.030)$ & $(0.028)$ & $(0.020)$ & $(0.006)$ & $(0.006)$ & $(0.029)$ & $(0.026)$ & $(0.026)$ \\
\hline \multirow[t]{2}{*}{ Kazakh } & 0.028 & -0.023 & $-0.048^{a}$ & $0.070^{c}$ & 0.048 & -0.009 & -0.014 & $-0.031^{b}$ & $-0.022^{b}$ & -0.009 & -0.042 & 0.020 \\
\hline & $(0.030)$ & $(0.014)$ & $(0.015)$ & $(0.039)$ & $(0.035)$ & $(0.030)$ & $(0.031)$ & $(0.011)$ & $(0.010)$ & $(0.045)$ & $(0.041)$ & $(0.038)$ \\
\hline \multirow[t]{2}{*}{ European } & -0.047 & $-0.066^{a}$ & $-0.098^{a}$ & -0.040 & $-0.073^{c}$ & $-0.132^{\mathrm{a}}$ & $-0.053^{c}$ & $-0.058^{a}$ & $-0.045^{a}$ & -0.071 & $-0.140^{a}$ & $-0.095^{b}$ \\
\hline & $(0.031)$ & $(0.014)$ & $(0.014)$ & $(0.042)$ & $(0.038)$ & $(0.034)$ & $(0.032)$ & $(0.011)$ & $(0.009)$ & $(0.047)$ & $(0.042)$ & $(0.041)$ \\
\hline \multirow[t]{2}{*}{ Tenure } & $-0.047^{a}$ & $-0.022^{a}$ & $-0.011^{b}$ & $-0.059^{a}$ & $-0.046^{a}$ & -0.013 & $-0.052^{a}$ & $-0.030^{a}$ & $-0.014^{a}$ & $-0.067^{a}$ & $-0.090^{a}$ & $-0.034^{\mathrm{a}}$ \\
\hline & $(0.008)$ & $(0.004)$ & $(0.004)$ & $(0.010)$ & $(0.009)$ & $(0.009)$ & $(0.008)$ & $(0.005)$ & $(0.003)$ & $(0.011)$ & $(0.009)$ & $(0.010)$ \\
\hline \multirow[t]{2}{*}{ Hours } & $-0.008^{a}$ & $-0.002^{b}$ & $-0.003^{b}$ & $-0.008^{\mathrm{a}}$ & -0.003 & $-0.004^{b}$ & $-0.008^{\mathrm{a}}$ & $-0.002^{a}$ & $-0.002^{a}$ & $-0.009^{\mathrm{a}}$ & -0.002 & $-0.005^{b}$ \\
\hline & $(0.001)$ & $(0.001)$ & $(0.001)$ & $(0.002)$ & $(0.002)$ & $(0.002)$ & $(0.001)$ & $(0.0007)$ & $(0.001)$ & $(0.001)$ & $(0.002)$ & $(0.002)$ \\
\hline \multirow[t]{2}{*}{ Professional } & $-0.123^{b}$ & $-0.063^{a}$ & $-0.100^{a}$ & -0.089 & -0.096 & $-0.194^{b}$ & -0.032 & $-0.074^{a}$ & $-0.059^{a}$ & 0.115 & -0.102 & -0.068 \\
\hline & $(0.047)$ & $(0.018)$ & $(0.018)$ & $(0.086)$ & $(0.070)$ & $(0.062)$ & $(0.048)$ & (0.009) & $(0.009)$ & $(0.071)$ & $(0.065)$ & $(0.061)$ \\
\hline \multirow[t]{2}{*}{ Urban } & $0.054^{b}$ & 0.008 & $0.024^{b}$ & $0.095^{\mathrm{a}}$ & $0.066^{b}$ & $0.084^{\mathrm{a}}$ & $0.092^{\mathrm{a}}$ & 0.001 & 0.008 & $0.147^{\mathrm{a}}$ & 0.031 & $0.085^{\mathrm{a}}$ \\
\hline & $(0.022)$ & $(0.010)$ & $(0.011)$ & $(0.028)$ & $(0.025)$ & $(0.023)$ & $(0.022)$ & $(0.006)$ & $(0.007)$ & $(0.029)$ & $(0.026)$ & $(0.026)$ \\
\hline
\end{tabular}


Table 8 Informality equation estimation results (marginal effects) (Continued)

\begin{tabular}{|c|c|c|c|c|c|c|c|c|c|c|c|c|}
\hline \multirow[t]{2}{*}{ Almaty/Astana } & $-0.135^{a}$ & -0.011 & $-0.040^{\mathrm{b}}$ & $-0.129^{b}$ & 0.066 & -0.050 & $-0.135^{\mathrm{a}}$ & $-0.021^{c}$ & $-0.047^{\mathrm{a}}$ & $-0.171^{b}$ & 0.039 & -0.091 \\
\hline & $(0.033)$ & $(0.019)$ & $(0.019)$ & $(0.060)$ & $(0.053)$ & $(0.050)$ & $(0.031)$ & $(0.012)$ & $(0.010)$ & $(0.061)$ & $(0.064)$ & $(0.058)$ \\
\hline $\mathrm{N}$ & 1647 & 1992 & 2300 & 1647 & 1992 & 2300 & 1566 & 1822 & 1716 & 1566 & 1822 & 1716 \\
\hline
\end{tabular}

Notes: Marginal effects (at mean) were computed in Stata using the "margeff" command written by Bartus (2005). Estimates based on unweighted regressions. Robust standard errors are in parentheses. Coefficients in bold are significant at: ${ }^{a} p<0.001,{ }^{b} p<0.01,{ }^{c} p<0.05$.

Dependent variable $=$ Informal 
percentage points in 2009. For men, the negative and significant effects in Astana and Almaty disappeared after the crisis struck. This result probably relates to the diminished relative attractiveness of formalisation in these two cities and variation in local government authorities' enforcement of mandated business regulations during the macro-economic crisis of 2008-09. Thus, some individuals find it difficult to comply in such an environment and simply perceive informal self-employment as a worthy alternative. Comparing the 'uncorrected' regression results with the double probit estimates, we find that the probit regression coefficients are different in statistical significance (e.g., Kazakh and Professional) and lower in magnitudes. Finally, the positive and significant selectivity coefficient (Rho) suggests positive sorting into selfemployment and indicates that it was necessary to correct for the selection bias problem. ${ }^{17}$

\subsection{Decomposition estimates}

Table 9 reports decomposition results of the change in the probability of informality before and after the crisis for each gender group. We find that the gap in mean informality probabilities in the pre- and post-crisis periods decreases from 36 percentage points to 20 percentage points for men and from 33 to 13 for women. Differences in characteristics explain roughly a quarter of the change for men and women, whilst the unexplained decline accounts for a significant portion of the observed change between the two periods. Our analysis of individual contributions indicates that a relatively high share of the explained change (over one-half) results largely from an increase in working hours and self-employment tenure after the crisis. For men (women), the contribution made by education to the 'endowment' part accounts for $17 \%(23 \%)$ of the decline in the average predicted probability of being informal.

Table 9 Decomposition of informality differences across gender: 2006 and 2011

\begin{tabular}{|c|c|c|c|c|}
\hline & \multicolumn{2}{|l|}{ Men } & \multicolumn{2}{|l|}{ Women } \\
\hline & 2006 & 2011 & 2006 & 2011 \\
\hline Predicted probability $[\operatorname{Pr}(\mid=1)]$ & $0.355(0.040)$ & $0.199(0.024)$ & $0.332(0.039)$ & $0.132(0.019)$ \\
\hline Difference $[\triangle / G A P]$ & $-0.156[100 \%]$ & & $-0.200[100 \%]$ & \\
\hline \multirow[t]{2}{*}{ Due to characteristics $\left[\operatorname{EXP}_{j \Delta t}\right]$} & $-0.039[-25 \%]$ & & $-0.048[-24 \%]$ & \\
\hline & \multicolumn{2}{|c|}{ Explained by $\left[\operatorname{EXP}_{j r \Delta t}\right]$} & & \\
\hline Age & -0.0010 & & $5 \times 10^{-5}$ & \\
\hline Children & 0.0001 & & -0.0010 & \\
\hline Education & -0.0066 & & -0.0109 & \\
\hline Married & 0.0001 & & 0.0002 & \\
\hline Kazakh & 0.0015 & & -0.0009 & \\
\hline European & 0.0036 & & 0.0054 & \\
\hline Tenure & -0.0184 & & -0.0168 & \\
\hline Hours & -0.0133 & & -0.0156 & \\
\hline Professional & -0.0010 & & -0.0005 & \\
\hline Urban & -0.0027 & & -0.0089 & \\
\hline Almaty/Astana & -0.0013 & & 0.0009 & \\
\hline
\end{tabular}

Notes: Probabilities evaluated at the mean value of variables. The estimated standard errors of the predictions, based on Stata's delta method command, are in parentheses. The explained part of the predicted change in informality rates between 2006 (period 0, pre-crisis) and 2011 (period 1, post-crisis) is attributed to the change in informality that occurs only if the composition value $(\Delta X)$ changes from period 0 to period 1 . 


\section{Conclusion}

Kazakhstan, over the period 2006-2011, experienced a twelve (sixteen) per cent reduction in informality levels amongst self-employed men (women). The objective of this paper is to explain these dynamics. We first estimate the determinants of entry into informal self-employment. Controlling for sample selection bias, we find that informality propensities are affected by age, place of residence, occupation and human capital. We also find strong evidence that supports the view that the economic crisis significantly increased the non-European minority group's informality propensities, from which they have yet to recover.

We examine changes in informality probabilities using the Gomulka and Stern (1990) method. The decomposition reveals that the 'treatment' component explains much of the decline in the average probability of informality between 2006 and 2011 for both men and women. It is likely that the large unexplained decline can result from structural changes such as changes in taxation that make one sector relatively more attractive than the other, employers' hiring and firing behaviour, changes in labour regulation and a change in preferences ('taste') for the informal sector. Another possible explanation for this finding is that the government introduced post-crisis reforms designed to ease the regulatory burden. For example, the government reduced the number of licensed activities and eased registration procedures in the late 2000s (OECD 2012). For both men and women, the most important contribution to the explained decline can be attributed to changes in average tenure. This result suggests that it is more efficient to help to reduce administrative costs and improve survival rates for new entrants. Evidence also suggests that the expansion of voluntary and decent part-time employment, combined with the principle of equal treatment, may offer a buffer against informality (Fagan et al. 2014).

In general, our analysis suggests that reducing informality may require coordinating actions rather than pursuing a few narrow, ostensibly distinct, policies. For example, the government can target the poorest groups in society with integrated and participatory approaches to facilitate their transition to formality through local economic development (International Labour Organization 2013). The finding that human capital helped to bring about the decline in informality suggests that the government should target informality through educational expenditures and skills development, enhancing productivity and earnings of workers.

\section{Endnotes}

${ }^{1}$ The International Labour Organization (ILO) argues that the policy environment surrounding growth shapes the way that the levels of informality respond to the crisis (International Labour Organization 2013).

${ }^{2}$ According to Kazakhstan Agency on Statistics (KAS), the number of own-account workers rose by 19.2\% (733,500 to 874,400) over the period of 2007 to 2009 (Kazakhstan Agency on Statistics 2014).

${ }^{3}$ We ignore other choices, such as participation in the labour market, as we would require separate identifiers; and the lack of identifiers, as well as the complexity in estimating double or multiple selection correction in our empirical section, explains this approach.

${ }^{4}$ The number of small and medium-sized enterprises (SMEs) rose sharply during the recovery period, but their economic importance, measured as contribution to GDP, fell 
from $20.4 \%$ to $17.3 \%$ over the period 2007-2012 (Kazakhstan Agency on Statistics 2014). We must also note that the economically active SMEs as a percentage of registered businesses averaged less than 70\% between 2007 and 2009 and fell to 53\% in the following year (Kazakhstan Agency on Statistics 2012, p. 19).

${ }^{5}$ According to recent estimates, the aggregate self-employment rate, if subsistence farmers are included, averaged 35\% over the period from 2005 to 2009 (World Bank 2015). It appears that the pattern of self-employment was comparable with that of Moldova and Romania over the same period. In other transition countries, by contrast, we find that average self-employment rates were less than half the Kazakh self-employment rate (e.g., Bulgaria and Slovak Republic).

${ }^{6}$ We must mention that following the economic transition, the quality of schooling deteriorated, particularly in rural areas (United Nations Development Programme 2004, p. 26). More recently, Ernst \& Young (2012, p. 14) found that the younger generation lacks the necessary practical and technical skills and therefore cannot replace the retiring Soviet-trained specialists. Further support for this view is provided by Rutkowski (2011, p.17). The author reports that over 50 per cent of respondent firms view an inadequately educated workforce as a major or severe constraint to the business environment.

${ }^{7}$ Kalyuzhnova and Nygaard (2011) cast doubt on the ability of the Kazakh government to select the 'right' places to allocate resources through the state financial vehicles for the purpose of economic diversification.

${ }^{8}$ It is, of course, possible that some workers may be displaced involuntary.

${ }^{9}$ It is hardly plausible to assume that the self-employed have similar characteristics, both observable and unobservable, to the sample of salaried workers, including employers.

${ }^{10}$ The solution was introduced for the first time by Van de Ven and Van Pragg (1981).

${ }^{11}$ The decomposition cannot be computed by plugging in the estimated $\hat{\gamma}$ and the mean values of $X$, as in the standard Oaxaca-Blinder technique. Counterfactual conditional expectations must instead be computed and averaged across observations. See Fairlie (2005) and Jann (2008) for the detailed discussion of the decomposition method for nonlinear response models.

${ }^{12}$ Jones (1983, p. 130) demonstrated that the unexplained portion of the gap "cannot be uniquely determined because the value for the difference in intercepts depends on measurement decisions." That is, the decomposition arbitrarily depends on the choice of the omitted group, and the elements of the detailed decomposition must rely upon arbitrary normalisations (Fortin et al. 2010, pp. 40-42). Yun's method overcomes this problem (see for example Yun 2005, p. 15 and Table 2). However, this correction does not change the characteristic effect, and this is what is important in this paper. The coefficient effect is important in the case of, say, race since it is interpreted as the upper limit of discrimination and we might want to know what contributes to discrimination part. However, in the case of informal-formal sector, particularly over time, it has no interpretation. Therefore, we do not attempt to estimate the separate contributions made by individual characteristics to the unexplained change.

${ }^{13}$ The collection of earnings data in the KLFS first began in 2013.

${ }^{14}$ For other reasons why they are excluded see International Labour Organization (2002).

${ }^{15}$ Gavrilovic et al. (2009) argued that there was insufficient provision of affordable child care, which, in turn, has "constrained women from taking on income-generating activities" (p. 27). 
${ }^{16}$ We do not find a U-shaped relationship between informality and age. Estimates can be provided by the authors on request.

${ }^{17}$ The full set of estimates can be found in an earlier version of this paper (see Mussurov and Arabsheibani 2013, Table 6).

\section{Competing interests}

The IZA Journal of Labor and Development is committed to the IZA Guiding Principles of Research Integrity. The authors declare that they have observed these principles.

\section{Acknowledgments}

We would like to thank Gerald Pech, Dena Sholk, Tulus Tambunan, Leon Taylor, and an anonymous referee for many helpful comments and suggestions on earlier drafts. We are also grateful to Zhansulu Baikenova, Ronald Mendoza, Zafar Nazarov, Edgard Rodriguez, Galina Semibratova, and several participants of the 2013 Enterprise Performance in Asia Conference held in Cebu City on 7-9 November 2013 for helpful discussions and comments. This work was conducted with the aid of a grant from Enterprise Performance in Asia, a project managed by the Asian Institute of Management Policy Center (Philippines) with funding from the International Development Research Centre (Canada). The normal disclaimer applies.

Responsible editor: Hartmut Lehmann

\section{Author details}

${ }^{1}$ Department of Economics, KIMEP University, Almaty 050010, Kazakhstan. ${ }^{2}$ London School of Economics, London, UK. ${ }^{3}$ IZA, Bonn, Germany.

Received: 14 September 2014 Accepted: 27 March 2015

Published online: 26 June 2015

\section{References}

Adom K, Williams CC (2012) Evaluating the motives of informal entrepreneurship in Koforidua, Ghana. J Dev Entrepren 17(1):1-17

Aidis R, Welter F, Smallbone D, Isakova N (2007) Female entrepreneurship in transition economies: The case of Lithuania and Ukraine. Fem Econ 13(2):351-377

Allen IE, Elam A, Langowitz N, Dean M (2007) The Global Entrepreneurship Monitor: Report on women entrepreneurship. Babson College, Babson Park, MA

Asian Development Bank (2013) Gender Assessment Report: Kazakhstan. ADB, Mandaluyong City, Philippines

Bartus T (2005) Estimation of marginal effects using margeff. Stata J 5(3):309-329

Burke A, Fitzroy F, Nolan M (2002) Self-employment wealth and job creation: The roles of gender, non-pecuniary motivation and entrepreneurial ability. Small Bus Econ 19:255-270

Chen MA (2012) The informal economy: Definitions, theories and policies. WIEGO Working Paper No. 1. http:// wiego.org/sites/wiego.org/files/publications/files/Chen_WIEGO_WP1.pdf. Accessed 21 May 2013

Damu Fund (2011) Closing the gender gaps in entrepreneurship: Support at the country level - experience of Damu. Chairperson's Report. Presented at UNECE policy seminar on women's entrepreneurship development in Central Asia, Geneva, 19 September 2011. http://www.unece.org/fileadmin/DAM/Gender/Events_Documents/2011/ PolicySeminarWED/Session3/Sess3_5_LI_ENG.pdf. Accessed 21 May 2013

Demirgüc-Kunt A, Klapper LF, Panos GA (2010) Entrepreneurship in post-conflict transition: the role of informality and access to finance. Econ Transit 19(1):27-78

Duban E (2012) Country gender assessment: Kazakhstan. Technical assistance consultant's report, project No: 44067. Asian Development Bank, Manila

Ernst \& Young (2012) 2012 Kazakhstan attractiveness survey. Ernst \&Young, Kazakhstan. http://emergingmarkets.ey.com/ wp-content/uploads/downloads/2012/05/Kz_attractiveness_final_LQ_36p.pdf. Accessed 9 Sept 2014

Even W, Macpherson D (1993) The decline of private-sector unionism and the gender wage gap. J Hum Resour 28(2):279-296

Fagan C, Norman H, Smith M, González Menéndez M (2014) In search of good quality part-time employment. Conditions of Work and Employment Series No. 43. International Labour Organization, Geneva

Fairlie RW (2005) An extension of the Blinder-Oaxaca decomposition technique to logit and probit models. J Econ Soc Meas 30(4):305-316

Fields GS (1975) Rural-urban migration, urban unemployment and underemployment, and job-search activity in LDCs. J Dev Econ 2(2):165-187

Fields GS (1990) Labour market modelling and the urban informal sector: Theory and evidence. In: Turnham D, Salomé B, Schwarz A (eds) The Informal Sector Revisited. OECD, Paris

Fiess N, Fugazza M, Maloney W (2010) Informal self-employment and macroeconomic fluctuations. J Dev Econ 91(2):211-226

Fortin N, Lemieux T, Firpo S (2010) Decomposition methods in economics. NBER Working Paper No. 16045. http://www.nber.org/papers/w16045. Accessed 20 June 2013

Gavrilovic M, Harper C, Jones N, Marcus R, Pereznieto P (2009) Impact of the Economic Crisis and Food and Fuel Price Volatility on Children and Women in Kazakhstan. Overseas Development Institute, London, http://www.odi.org.uk/ sites/odi.org.uk/files/odi-assets/publications-opinion-files/5827.pdf. Accessed 2 Aug 2013

Georgellis Y, Sessions JG, Tsitsianis N (2005) Self-employment longitudinal dynamics: A review of the literature. Econ Issues 10(2):51-84

Gimpelson VE, Kapeliushnikov R (2013) Нормально ли быть неформальным? (Is it normal to be informal?). HSE Econ J 17(1):3-40 
Gomulka J, Stern N (1990) The employment of married women in the United Kingdom 1970-1983. Economica 57:171-200 Hart K (1972) Employment, Income and Inequality: A Strategy for Increasing Productive Employment in Kenya. ILO, Geneva

Hart K (1973) Informal income opportunities and urban employment in Ghana. J Mod Afr Stud 11:61-89

Hazans M (2011) Informal workers across Europe: Evidence from 30 countries. IZA Discussion Paper No. 5871

Henley A, Arabsheibani GR, Carneiro FG (2009) On defining and measuring the informal sector: Evidence from Brazil. World Dev 37(5):992-1003

International Finance Corporation (2011) Strengthening Access to Finance For Women-Owned SMES in Developing Countries. IFC, Washington, DC

International Labour Organization (1990) ISCO-88: International Standard Classification of Occupations. ILO, Geneva International Labour Organization (2002) Women and Men in the Informal Economy: A Statistical Picture. ILO, Geneva International Labour Organization (2012) Statistical Update on Employment in the Informal Economy. ILO, Geneva International Labour Organization (2013) The Informal Economy and Decent Work: A Policy Resource Guide Supporting Transitions to Formality. ILO, Geneva

Jann B (2008) The Blinder-Oaxaca decomposition for linear regression models. Stata J 8(4):453-479

Jones FL (1983) On decomposing the wage gap: A critical comment on Blinder's method. The J of Hum Resour 18(1):126-130

Kalyuzhnova Y, Nygaard CA (2011) Special vehicles of state intervention in Russia and Kazakhstan. Comp Econ Stud 53:57-77

Kanbur R (2011) Avoiding informality traps. In: Ghani E (ed) Reshaping Tomorrow: Is South Asia Ready for the Big Leap? Oxford University Press, Oxford, pp 260-278

Kantor P (2001) Promoting women's entrepreneurship development based on good practice programmes - some experiences from the North to the South. SEED Working Paper No. 9. ILO, Geneva

Kazakhstan Agency on Statistics (2012) Small and Medium Enterprises in The Republic Of Kazakhstan, 2007-2011. KAS, Astana

Kazakhstan Agency on Statistics (2014) Main indicators of small businesses, 1999-2013. KAS, Astana. http:// www.stat.gov.kz/faces/wcnav_externalld/homeNumbersSMEnterprises?_adf.ctrlstate $=$ pokcm1s9u_4\&_afrLoop=216552688462778. Accessed 14 March 2015

Lehmann H, Pignatti N (2007) Informal employment relationships and labour market segmentation in transition economies: Evidence from Ukraine. IZA Discussion Paper No. 3269

Lehmann H, Razzolini T, Zaiceva A (2012) Job separations and informality in the Russian labor market. Res Labor Econ $34: 257-290$

Leoni T, Falk M (2008) Gender and field of study as determinants of self-employment. Small Bus Econ 34(2):167-185

Maloney WF (2004) Informality revisited. World Dev 32(7):1159-1178

Mussurov A, Arabsheibani GR (2013) Informal Self-Employment in Kazakhstan. AIM WP 14-006, Asian Institute of Management, Makati City, Philippines, http://papers.ssrn.com/sol3/papers.cfm?abstract_id=2429398. Accessed 10 March 2015

Organisation for Economic Co-operation and Development (2012) OECD Investment Policy Reviews. OECD Publishing, Kazakhstan 2012, doi: 10.1787/9789264121812-en

Parker SC (2004) The Economics of Self-Employment and Entrepreneurship. Cambridge University Press, Cambridge

Perry GE, Maloney WF, Arias OA, Fajnzybler P, Mason AD, Saavedra-Chanduvi J (eds) (2007) Informality: Exit and Exclusion. The World Bank, Washington, DC

Rutkowski J (2006) Labor Market Developments During Economic Transition. World Bank Policy Research WP 3894. The World Bank, Washington, DC

Rutkowski J (2011) Promoting formal employment in Kazakhstan. Paper presented at IZA/World Bank workshop on institutions and informal employment in emerging and transition economies, IZA, Bonn, 9-11 June 2011. http://www.iza.org/conference_files/InfoETE2011/rutkowski_j1928.pdf. Accessed 23 Feb 2013

Slonimczyk F, Gimpeslon V (2015) Informality and mobility. Econ Transit 23: 299-341. doi: 10.1111/ecot.12064

Staneva A, Arabsheibani GR (2013) Is there an informal wage premium? Evidence from Tajikistan. J Labor Dev 3(1):1-24

Terrell K, Troilo M (2010) Values and female entrepreneurship. Int J Gend Entrepren 2(3):260-286

Yun M-S (2005) Normalized equation and decomposition analysis: Computation and inference. IZA Discussion Paper No. 1822

United Nations Development Programme (2004) Kazakhstan National Human Development Report 2004: Education for all. UNDP, Almaty, Kazakhstan

Van de Ven WPMM, Van Praag BMS (1981) The demand for deductibles in private health insurance: A probit model with sample selection. J Econometrics 17(2):229-252

Verme P (2001) Transition, Recession and Labour Supply. Ashgate Press, Aldershot

World Bank (2012) World Development Report 2012: Gender equality and Development. The World Bank, Washington, DC

World Bank (2013a) World Development Report 2013: Jobs. The World Bank, Washington, DC

World Bank (2013b) World Development Indicators. The World Bank, Washington, DC

World Bank (2015) The Data Catalog: Self-employed, total (\% of total employed). http://data.worldbank.org/indicator/ SL.EMP.SELF.ZS?page=1. Accessed 4 March 2015 